\title{
A Brief History of Electricity, Magnetism, and Radio Science in Finland
}

\author{
Ari Sihvola
}

\begin{abstract}
This letter reviews historical milestones concerning the studies of electricity, magnetism, and radio science in Finland. Even if the first university on Finnish ground started as early as 1640, the first dissertation concerning electricity was not defended (by Gustav Polviander) until 1772. The discovery of electromagnetism in the early 19th century inspired Johan Jacob Nervander to design a sensitive galvanometer, and the invention of wireless communication brought radio waves to Finland with the experiments of A. S. Popov. Since then, research and applications within the field have been expanding tremendously, resulting in a vibrant radio-science community in Finland.
\end{abstract}

\section{Introduction}

Radio science rests on the foundations of electromagnetics, a scientific discipline that was quantitatively formulated in the late 19th century and ultimately codified into the Treatise on Electricity and Magnetism by James Clerk Maxwell [1]. His groundbreaking achievement not only set the scene for electrodynamics but also helped Albert Einstein formulate his special theory of relativity. Well known is the anecdote which tells about Einstein's respect for Maxwell: "I do not stand on the shoulders of Newton, but on the shoulders of Maxwell."

But Maxwell stood on shoulders of others. Electric and magnetic phenomena were familiar to humanity for millennia: Thales, the ancient Greek philosopher, spoke about the strange power of rubbed amber (in Greek, "elektron"), and the magnetic effects of iron were reported a long time ago by the Roman sages Pliny the Elder [2] and Titus Lucretius Carus [3].

As the centuries passed, the understanding of electricity and magnetism grew. Petrus Peregrinus in the late Middle Ages wrote his Epistola [4] about magnetic poles of the lodestone and Earth's magnetism. Gilbert's De Magnete [5], from 1600, was a comprehensive discussion on the topic not only of magnetism but also of static electricity.

The 18th century saw the beginnings of quantitative electrostatics through the works of CharlesAugustin de Coulomb, then the electric battery was created by Alessandro Volta in 1800, and finally electromagnetism was discovered by Hans Christian Ørsted in 1820 with his observation of the magnetic

Manuscript received 21 December 2021.

Ari Sihvola is with the Department of Electronics and Nanoengineering, School of Electrical Engineering, Aalto University, Espoo, Finland; e-mail: ari.sihvola@aalto.fi. force of an electric current. The complementary effect, generating electricity from magnetism, was the result of Michael Faraday's investigations in 1831. But electromagnetic theory was not yet fully developed: the concept of displacement current was essential in a consistent set of electrodynamic equations. And this was formulated by Maxwell in his articles in the 1860s.

Parallel to these developments, scientific studies of electricity and magnetism were also cultivated in Finland. In the following, I will raise certain salient discoveries in the history of the intellectual developments of electromagnetism and radio science in Finland.

\section{The 17th Century}

Finland was by no means the center of civilization in Europe in previous centuries. Nevertheless, already in the 14th century several Finnish young men were sent to search for education in European universities. It was not until 1640 that the first university was founded in present-day Finland. A decree of Queen Christina (reigning 1632-1654) established the Royal Academy of Turku (Abo). Its mission was to educate priests, medical doctors, military officers, and administrators to serve the crown (Finland was the eastern part of the Sweden for centuries, including the period 1611-1721 when Sweden was a superpower in Europe). The first doctoral dissertation in Finland (and the first printed book in Finland, for that matter) was 1641's Discursus politicus de prudentia (A political discussion on prudence) [6] by Mikael Wexionius, which was defended by his student Enevaldus Svenonius Pontanus. However, natural sciences were not the focus of research and education during this century. Furthermore, the Great Northern War and in particular the devastating Great Wrath (1713-1721) closed the activities of the university for several years.

\section{The 18th Century}

The 1700s have been called the century of enlightenment, which also flourished in Sweden and Finland. Like today, the strategic goals of the university focused on applications, research based on reason was intended to serve the public good, and fields like plant breeding and agriculture were important. Investigations of physical and chemical phenomena received attention. Despite the fact that electricity at that time was not considered a hot topic in the scientific community, there was some interest in it in Finland.

The first doctoral-thesis defense on electrical phenomena in Finland took place on 6 May 1772, in 


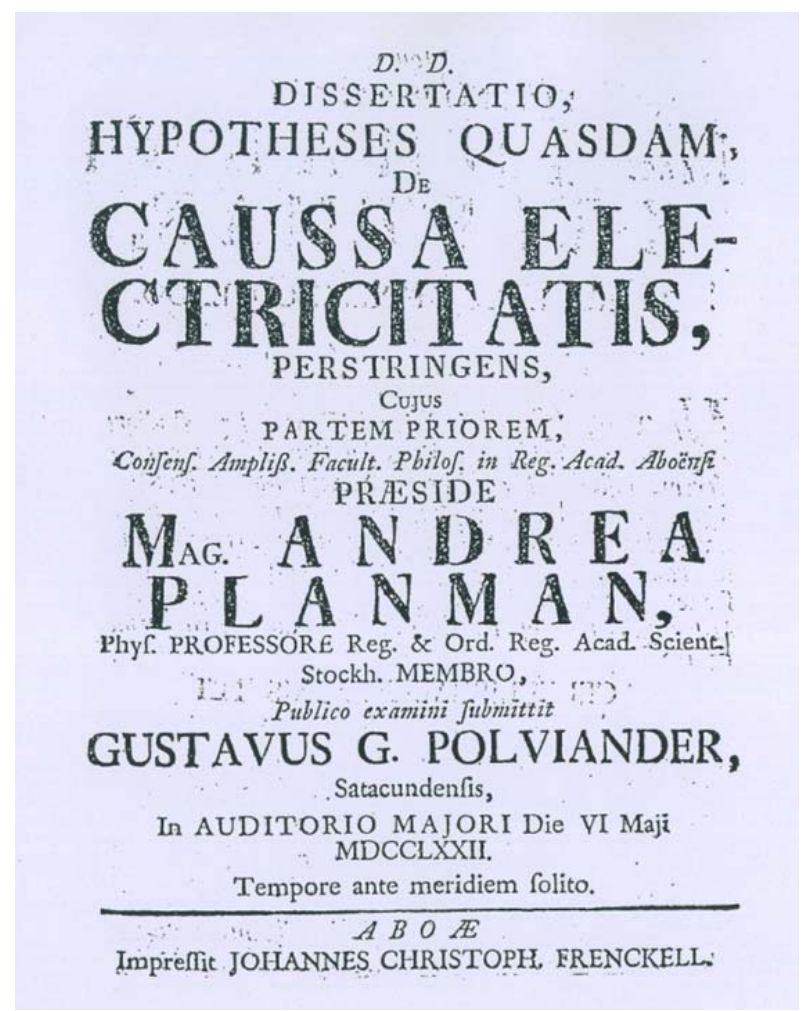

Figure 1. The first doctoral thesis on electricity in Finland, defended by "Gustav G. Polviander, from Satakunta, in the Main Hall of the University, at the usual time a.m., on May 6, 1772."

the Royal Academy of Turku (Figure 1). Gustav Polviander defended the understanding of static electricity in the thesis Hypotheses Quasdam de Caussa Electricitatis (Hypotheses on the foundations of electricity) [7]. In this publication one can find references to many of the pioneers and central actors the field: William Gilbert, Stephen Gray, Charles du Fay, Benjamin Franklin, Samuel Klingenstierna, and Johann Albrecht Euler, among others.

\section{The 19th Century}

The Napoleonic wars strongly affected the political landscape in Scandinavia. From the Finnish perspective, the change was radical: in 1809, Finland was ceded from the Kingdom of Sweden to become an autonomous grand duchy of the Russian Empire. Furthermore, after a catastrophic fire in Turku in 1827, the university was moved to the new capital, Helsinki. The Royal Academy received a new name Imperial Alexander University, after Emperor Alexander I (reigning 1801-1825), due to his generous financial support.

The early 19th century saw the birth of electromagnetism, which did not happen unnoticed in Finland. One of the young graduates of the new university, Johan Jacob Nervander (1805-1848), entered with full force into studying the magnetic effect of galvanic electric current and accurate measurement of the Earth's

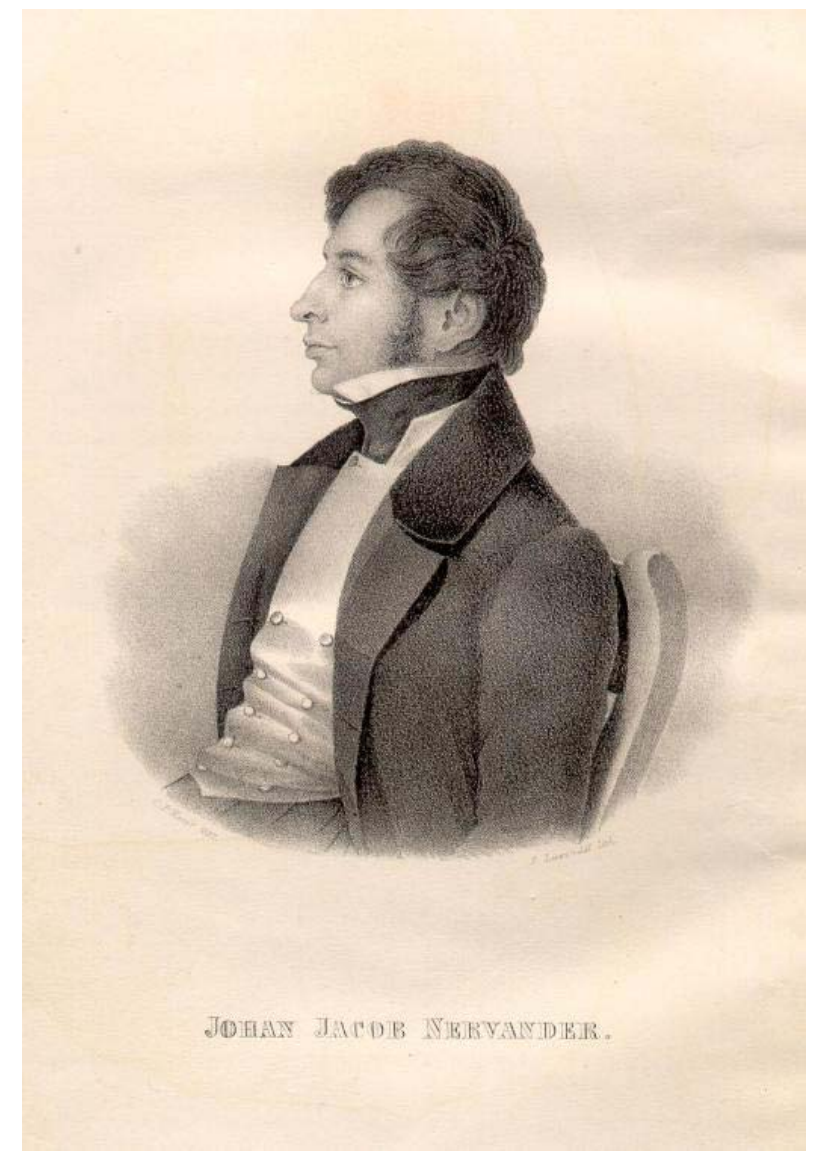

Figure 2. Johan Jacob Nervander (1805-1848), lithograph by Frans Oskar Liewendahl, based on a painting by Carl Petter Mazér (1837), in the Antell and Wadström collections, Museovirasto. (Source: Finnish Heritage Agency; used under Creative Commons Attribution 4.0 International Public License.)

magnetic field [8]. Nervander (Figure 2) had good contacts both with the leading European scientists and with the political administration in the imperial capital of St. Petersburg. Hence he managed to organize the building of a magnetic observatory in Helsinki. This provided decade-long measurements and valuable data about the temporal variations of the geomagnetic flux over different time scales [9].

One of Nervander's most important contributions to electrical science is the so-called "tangentbussol," a galvanometer with which the magnitude of electric current could be quantified. He presented his instrument to the French Academy of Sciences in its meeting in Paris on 3 March 1834 [10]. It is worth noting that the concept of electric current came in use only later, once the work Die galvanische Kette by Georg Simon Ohm gained acceptance. Although galvanometer prototypes had been presented soon after Ørsted's discovery by J. S. C. Schweigger, L. Nobili, and C. Pouillet, it is impossible to understate the innovativeness of Nervander's tangentbussol: its extreme sensitivity derived much from the structural design, in which the current-carrying coils were wound in a manner that 


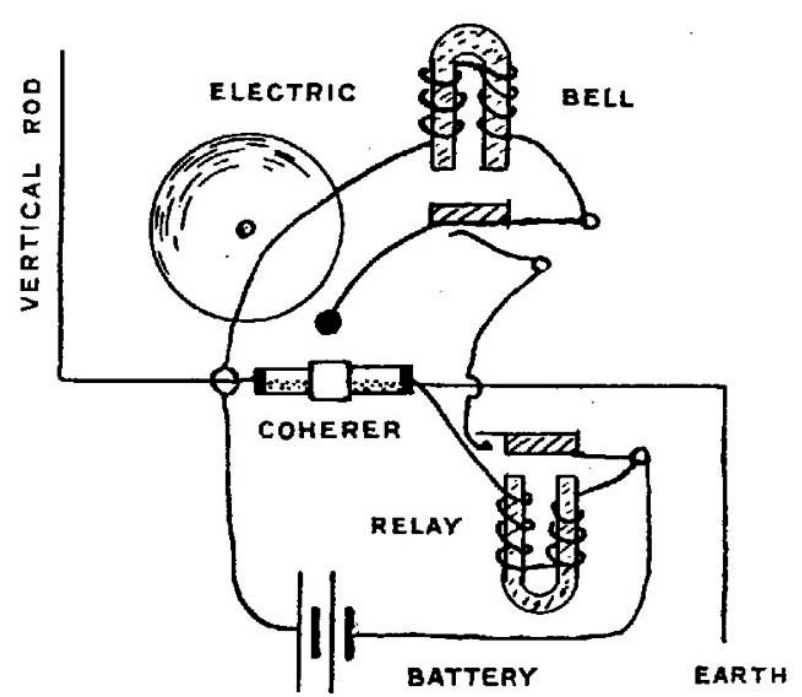

Figure 3. Popov's apparatus for the reception of radio disturbances. Note the essential circuit element ("coherer"), capable of changing itself into a conducting state when excited by an electric pulse from the antenna. The resulting current triggers electromagnets with the effect of a bell sound, followed by a knock on the coherer to bring it back into an insulating state.

emulated a continuous surface current around a box containing a long magnetic needle.

\section{Toward the 20th Century}

Even though Maxwell's electrodynamic theory was presented in the early 1860 s, it took a long time before the exploitation of radio waves for various purposes was possible. First, the empirical confirmation that electromagnetic waves behave like light happened only in the late $1880 \mathrm{~s}$, with the experiments in Karlsruhe by Heinrich Hertz. Moreover, Hertz did not see the possibilities of his waves being able to carry information. Wireless communications were invented in the last years of the century, by Guglielmo Marconi (1874-1937) in Italy and Alexander S. Popov (18591906) in Russia.

Indeed, one thread of the history of radio science in Finland is connected to Popov. He demonstrated the transmission of information by radio waves in 1896 (Figure 3), and some years later was able make use of his apparatus in a hostile marine environment. In 1899, the Russian battleship General-Admiral Apraksin ran aground in the Gulf of Finland. Popov was called to establish a communication link to assist in the rescue operation. He built a $40 \mathrm{~km}$ long radio link from the coastal town of Kotka (in present-day Finland) to Hogland island, where the ship was wrecked.

In the domain of electromagnetic modeling of materials, a fundamental scientific discovery was made by Karl Ferdinand Lindman [11, 12]. In 1914 in Helsinki, he showed the effect of rotation of the polarization plane of a radio wave as it propagates through handed media (Figure 4). In today's electromagnetic terminology, objects that are different from
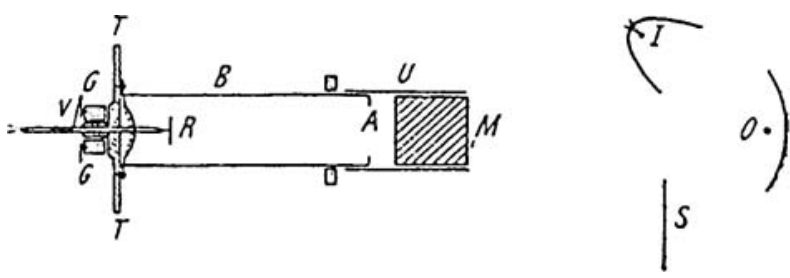

Figure 4. Lindman's experimental setup. His artificial chiral medium sample (cotton-packed copper spirals) resides in box $M$, through which the wave propagates into the hollow tube $B$. The transmitting oscillator $O$ is located in front of a reflector. The receiver dipole $R$ can be rotated with the stick $T$ to find the angle at which the received wave is maximum. Reproduced from [11], with permission.

their mirror image are called chiral, and hence one could say that Lindman was experimenting with chiral media. He immersed copper helices (all of the same handedness) into cotton balls in random orientations, and sent a linearly polarized radio wave through this ensemble, observing the rotation of the polarization. For propagation of visible light, it was known from studies by Biot and Pasteur (in the first half of the 19th century) that parity-breaking liquids, like tartaric acids, display this type of rotatory power, so-called optical activity. Instead of such natural organic materials, Lindman fabricated artificial chiral media, effective in the microwave region.

The use of radio waves for communications started to expand in the beginning of the century, all over the world. Public-service radio broadcasting saw its beginnings in Finland in 1926, and commercial activities in radio technology and electronics started to expand. Also in academia, radio engineering was considered important: in 1923, a chair in radio engineering was established at the Helsinki University of Technology. It took some time, however, before the first doctoral degrees were granted in Finland. The first was gained by Jouko Pohjanpalo in 1941, with the thesis A Method to Improve the Efficiency of a Modulated Radio Transmitter. It was written in Finnish, but the next ones were already in English: Pentti Mattila (Detection of Weak Periodic Signals from Noise, 1955) and Martti Tiuri (Investigations of Radio Reflections from Satellite-Produced Ion Trails Using 100 Mc CW Radar, 1960).

\section{The 21st Century}

Applications of electromagnetics and radio science penetrate everywhere in today's society. New innovations make use of multiple technologies, which makes it difficult to define the boundaries of radio science in the present century. One possibility for answering the question "What is radio science?" is to follow the classification of the International Union of Radio Science (URSI).

The ten commissions of URSI are A: Electromagnetic Metrology, B: Fields and Waves, C: Radiocommunication Systems and Signal Processing, D: Electronics and Photonics, E: Electromagnetic Envi- 
ronment and Interference, F: Wave Propagation and Remote Sensing, G: Ionospheric Radio and Propagation, H: Waves in Plasmas, J: Radio Astronomy, and K: Electromagnetics in Biology and Medicine.

The union is already over 100 years old: it was founded soon after World War I. Finland, despite being a small nation, joined the union early: the Finnish national member committee was formed in 1953 [13]. Finnish radio scientists have had a strong engagement in the activities of URSI over the decades. Examples of URSI commissions to which Finnish research has contributed are B (fundamental electromagnetics research including wave-material interaction modeling and metamaterials), F (remote sensing of snow, ice, sea, and forests), $\mathrm{G}$ and $\mathrm{H}$ (magnetospheric and space weather studies, in particular by contributing to the operations of the European Incoherent Scatter Scientific Association), and $\mathrm{J}$ (radio astronomical research on celestial objects from the nearby solar system all the way to distant galaxies, quasars, and other deep-sky objects).

\section{References}

1. J. C. Maxwell, A Treatise on Electricity and Magnetism, Oxford, Clarendon Press, 1873.

2. Pliny the Elder, Naturalis historiae (Natural History), Leipzig, Germany, Bibliotheca Scriptorum Graecorum et Romanorum Teubneriana, 1906.

3. Titus Lucretius Carus, De rerum natura (On the Nature of Things), H. A. J. Munro (trans.), London, George Routledge \& Sons, 1884.

4. Petrus Peregrinus de Maricourt, Epistola Petri Peregrini de Maricourt ad Sygerum de Foucaucourt, militem, de magnete (Letter of Peter Peregrinus of Maricourt to Sygerus of Foucaucourt, Soldier, on the Magnet), Brother
Arnold (trans.), New York, McGraw Publishing Co., 1904.

5. William Gilbert, De Magnete, Magneticisque Corporibus, et de Magno Magnete Tellure (On the Magnet and Magnetic Bodies, and on That Great Magnet the Earth), London, Peter Short, 1600.

6. Michael Wexionius, Discursus Politicus de Prudentia, I. Kajanto (trans.), Helsinki, Bibliofiilien Seura, 1983.

7. Gustav Polviander, Hypotheses Quasdam de Caussa Electricitatis (Hypotheses on the Foundations of Electricity), E. Voipio (trans.), Electromagnetics Laboratory Report Series 17, Espoo, Helsinki University of Technology, 1994.

8. A. Sihvola, "Johan Jacob Nervander and the Quantification of Electric Current," IEEE Antennas and Propagation Magazine, 63, 1, February 2021, pp. 123-128.

9. H. Nevanlinna, "Results of the Helsinki Magnetic Observatory 1844-1912," Annales Geophysicae, 22, 5, 2004, pp. 1691-2004.

10. J. J. Nervander, "Mémoire sur un Galvanomètre à châssis cylindrique par lequel on obtient immédiatement et sans calcul la mesure de l'intensité du courant électrique qui produit la déviation de l'aiguille aimantée," A. Sihvola (trans.), Electromagnetics Laboratory Report Series 23, Espoo, Helsinki University of Technology, 2005.

11. K. F. Lindman, "Om en genom ett isotropt system av spiralformiga resonatorer alstrad rotationspolarisation av de elektromagnetiska vågorna," Öfversigt av Finska Vetenskaps-Societetens Förhandlingar: A. Matematik och naturvetenskaper, 57, 3, 1914, pp. 1-32.

12. I. V. Lindell, A. H. Sihvola, and J. Kurkijärvi, "Karl F. Lindman: The Last Hertzian, and a Harbinger of Electromagnetic Chirality," IEEE Antennas and Propagation Magazine, 34, 3, June 1992, pp. 24-30.

13. A. Sihvola and H. Wallén, "120 Years of Radio Science in Finland," in P. Wilkinson, P. S. Cannon, and W. R. Stone (eds.), 100 Years of the International Union of Radio Science, Ghent, Belgium, International Union of Radio Science, 2021, pp. 81-89. 